\title{
Unsafe Drinking Water - Impact on Health and Economy
}

\author{
Mohan Lal Bhootrani, Aneela Atta-u-Rehman
}

This Editorial may be cited as: Bhootrani ML, Rehman AA. Unsafe Drinking Water - Impact on Health and Economy. J Liaquat Uni Med Health Sci. 2017;16(01):01-02.

doi: $10.22442 /$ jlumhs.171610496

Since the civilization \& before that historically human settlement had been always near to availability of water resources that may be rivers, wells, springs and other sources, without water human can survive just few days, ultimately leading to death; unfortunately now even with the availability of contaminated water for majority of population in Pakistan and world over we are inviting death.

Water is mainly classified in four groups; potable water, clean water, polluted water \& contaminated water ${ }^{1}$.

The public health care system mainly comprises of preventive health and curative one. The more important and strong part of this system must be preventive. There are many etiological factors causing various diseases but here we will be specific to water borne diseases, which is not only hazardous to health but also big economical burden on the budget of Pakistan to treat the disease thereafter using polluted \& contaminated water billions of rupees are spent every year by government and public.

This economic burden on public is taken under the heads of cost of medical treatment, cost of transport, food and absent from working thus indirectly decreasing the productivity of our population.

Availability of safe drinking water is not only problem for our country but most of the third world countries, as result of this neglect every year. 250,000 Pakistani children die under the age of 5 years and we spent 1.3 billion US $\$$ annually, a big economic burden as cost for treatment ${ }^{2}$.

In search of safe drinking water a portion of population who can afford the bottled drinking water spend huge amount of money but fact is that most of the brands of mineral water marketed in Pakistan are unsafe and contains contaminated water in plastic bottles, means even after paying for safe water public is unsafe this may be because of the negligence and lack of vigilance on the manufacturers. Many have no licenses for marketing the brand and on government side no proper system for evaluating \& lab testing is properly functioning before product reaches in the public hands. This situation exists not only in rural areas of the country but even urban areas are not less affected.

In a study in capital of Pakistan \& twin city Rawalpindi revealed that $94 \%$ and $34 \%$ of water samples respectively were contaminated with coliforms and faecal coliforms ${ }^{3}$.

An study conducted by Pakistan council of Research in water resources (PCR WR) in all four provinces of country reveals that an average $84 \%-89 \%$ of water quality is below the recommended standards for human consumption (PCRWR, 2008).

There are many active pollutants of water classified in different groups; the commonest among these are Bacteria, viruses and protozoa.

Inorganic pollutants include acids, salt, toxic metals Anion, cations, nitrates, phosphates, sulphates, $\mathrm{Ca}^{+1}$, $\mathrm{Mg}^{+2}$ and $\mathrm{F}^{-1}$, water soluble radioactive substances, in addition organic compounds like oil and pesticides are also included ${ }^{3}$.

United Nations (UN) reported that India's water quality is poor, it ranks $120^{\text {th }}$ among the 122 nations in terms of quality of water available to its citizens and Pakistan stood at $80^{\text {th }}$ number, further this report reveals that diarrheal disease account for an estimated $4.1 \%$ of the total daily global burden and 1.8 million human deaths annually ${ }^{4}$.

The WHO (World Health Organization) estimates that $88 \%$ of that burden is attributed to unsafe water supply, sanitation and hygiene ${ }^{3}$.

We can reduce mortality and save money by taking the measures and good effective planning to provide the safe drinking water to our public rather then spending more on curative side. Unfortunately very small percentage of budget is allocated for the health which should be more then any other sector. Proper utilization with good planning enables us to achieve the objectives. It is truly said prevention is better then cure.

It is further suggested we must comply with the recommendations of recent report of the commission of inquiry on water supply in Sindh submitted to Supreme Court of Pakistan on February 25, 2017, these suggestions may be extended for practical application in the country ${ }^{5}$.

\section{REFERENCES}

1. Public Health \& Community Medicine, $7 e(\mathrm{pb})$ 2007; Time traders. Pakistan.

2. Chaudhry S. Water borne diseases claim 250,000 children's lives every year. Daily Times[Internet]. June 05, 2016. Available from: http:// 
dailytimes.com.pk/islamabad/05-Jun-16/ waterborne-diseases-claim-250000-childrens-lives -every-year.

3. Azizullah A, Khattak MNA, Richter P, Hader DP. Water pollution in Pakistan and its impact on public health - A review. Environ Int. 2011;37:479 $-97$.
4. Pathak $\mathrm{H}$. Effect of water borne diseases on Indian economy: a cost benefit analysis. analele universităţii din oradea-seria geografie. 2015; 1:74-8.

5. Supreme Court of Pakistan Report of commission of inquiry [Internet]. February 25, 2017. Available from www.supremecourt.gov.pk

AUTHOR AFFILIATION:

Dr. Mohan Lal Bhootrani (Corresponding Author) Department of Pharmacology

Liaquat University of Medical \& Health Sciences

(LUMHS), Jamshoro, Sindh-Pakistan.

Email: bhootrani@gmail.com

Prof. Aneela Atta-u-Rehman

Faculty of Community \& Public Health Sciences

LUMHS, Jamshoro, Sindh-Pakistan. 